\title{
Thyroglossal duct cyst presenting as a large isolated mass within the middle mediastinum
}

\author{
Aliasghar Alavi, ${ }^{1}$ Mehrnaz Asadi Gharabaghi ${ }^{2}$
}

${ }^{1}$ Department of Thoracic Surgery, Advanced Thoracic Research Center, Tehran University of Medical Sciences, Iran

${ }^{2}$ Department of Pulmonary Medicine, Advanced Thoracic Research Center, Tehran University of Medical Sciences, Iran

\section{Correspondence to} Dr Mehrnaz Asadi Gharabaghi, asadi_m@tums.ac.ir

Accepted 13 March 2015

\section{(a) CrossMark}

To cite: Alavi A, Asadi Gharabaghi M. BMJ Case Rep Published online: [please include Day Month Year] doi:10.1136/bcr-2015209643

\section{DESCRIPTION}

A 55-year-old man visited our clinic with a history of several months dry cough and a vague retrosternal pain. He did not report of fever, weight loss, sputum or exertional dyspnoea. The findings were normal on physical examination. There was a large mediastinal mass on chest X-ray (figure 1A). Chest CT revealed a large middle mediastinal mass on the right side (figure 1B). There was no concurrent neck abnormality. The patient underwent right thoracotomy. On gross examination, the cyst was a large thin-walled cystic mass measuring approximately $7 \times 7 \mathrm{~cm}^{2}$. The surgical diagnosis was a bronchogenic cyst. However, on microscopic examination it was diagnosed to be a thyroglossal duct cyst based on the presence of variable-sized thyroid follicles with occasional pseudopapillary projections, filled with colloid material, and with a benign cyst wall lined by flat epithelial cells (figure 2). The patient passed the postoperative period uneventfully. To the best of our knowledge, this is the first case of large isolated middle mediastinal thyroglossal duct cyst without accompanying neck abnormality. Thyroglossal duct cyst is the most common congenital abnormality in the neck occurring anywhere

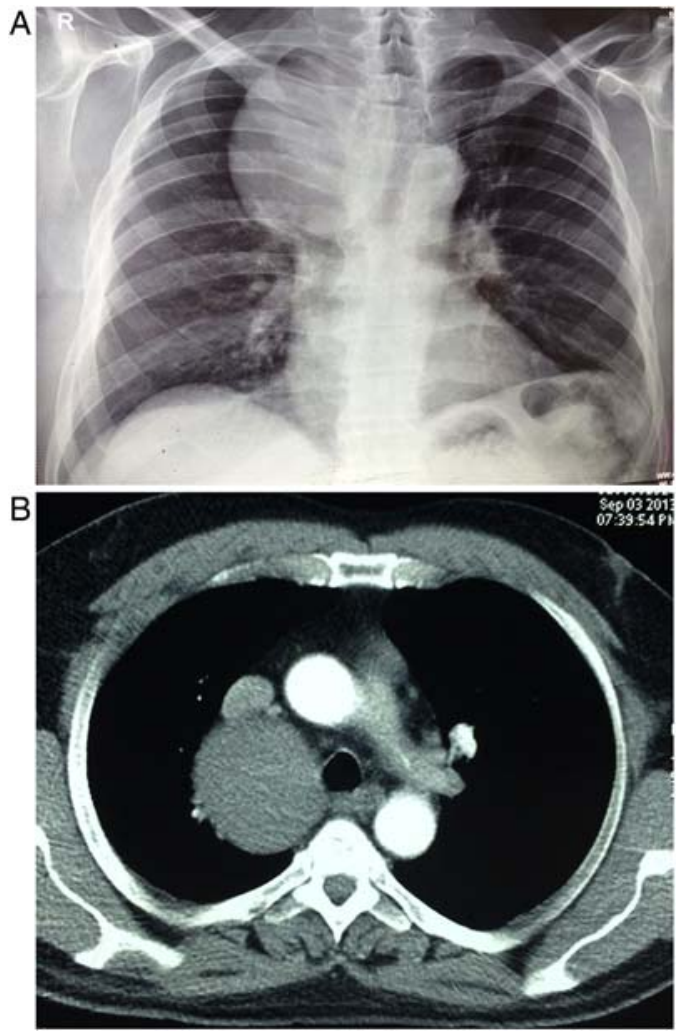

Figure 1 ( $A$ and $B$ ) Chest imaging shows a large middle mediastinal mass.

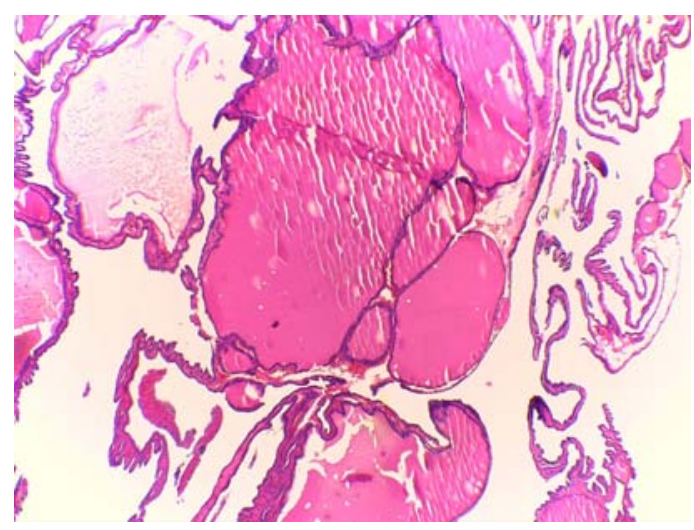

Figure 2 Histological review of the mass showing it to be a thyroglossal duct cyst, based on the presence of variable-sized thyroid follicles with occasional pseudopapillary projections, filled by colloid material, and with a benign cyst wall lined by flat epithelial cells.

from the foramen caecum to the hyoid bone. The occurrence below the hyoid, especially within the mediastinum without neck abnormality, is extremely rare. There are two other reports of mediastinal thyroglossal duct cyst in the literature in adult patients. ${ }^{12}$ Total surgical resection is the treatment of choice; care must be paid to the risk of recurrence. We believe that reports of such cases may enhance physicians' vigilance of thyroglossal duct cysts as a rare cause of mediastinal mass.

\section{Learning points}

- Thyroglossal duct cyst is a rare cause of mediastinal mass.

- It may present as a mediastinal mass without any neck abnormality.

- The definite treatment for mediastinal thyroglossal duct cyst is surgery and patient follow-up is necessary.

Competing interests None.

Patient consent Obtained.

Provenance and peer review Not commissioned; externally peer reviewed.

\section{REFERENCES}

1 Granato F, Roberts F, West D. A thyroglossal duct cyst of the anterior mediastinum. Ann Thorac Surg 2011;92:1118-20.

2 Chon SH, Shinn SH, Lee CB, et al. Thyroglossal duct cyst within the mediastinum: an extremely unusual location. I Thorac Cardiovasc Surg 2007;133:1671-2. 


\section{Images in...}

Copyright 2015 BMJ Publishing Group. All rights reserved. For permission to reuse any of this content visit http://group.bmj.com/group/rights-licensing/permissions.

BMJ Case Report Fellows may re-use this article for personal use and teaching without any further permission.

Become a Fellow of BMJ Case Reports today and you can:

- Submit as many cases as you like

- Enjoy fast sympathetic peer review and rapid publication of accepted articles

- Access all the published articles

- Re-use any of the published material for personal use and teaching without further permission

For information on Institutional Fellowships contact consortiasales@bmjgroup.com

Visit casereports.bmj.com for more articles like this and to become a Fellow 